Article

\title{
Petrogenesis and Geological Implications of the Oligocene Mingze monzodiorites, Southern Lhasa
}

\author{
Kailiang Zhang ${ }^{1, *}$, Zeming Shi ${ }^{1,2, *}$, Rong Liao ${ }^{1}$ and Feilin Zhu ${ }^{1,2}$ \\ 1 College of Earth Science, Chengdu University of Technology, Chengdu 610059, China; \\ liaorong@cdut.edu.cn (R.L.); zhufeilin2000@163.com (F.Z.) \\ 2 Applied Nuclear Technology in Geosciences Key Laboratory of Sichuan Province, Chengdu University of \\ Technology, Chengdu 610059, China \\ * Correspondence: kailiangzhang@stu.cdut.edu.cn (K.Z.); shizm@cdut.edu.cn (Z.S.)
}

Received: 25 February 2020; Accepted: 25 March 2020; Published: 27 March 2020

check for updates

\begin{abstract}
The Mingze Cu-Mo deposit is located in the southern margin of the Lhasa block of the Himalayan Tibetan Plateau. Here, we report the geochronological and geochemical data from Mingze monzodiorites, which hosts the Mingze deposit. Zircon dating indicates that the Mingze monzodiorites were emplaced at ca. $31 \mathrm{Ma}$ (i.e., the Oligocene). The monzodiorites have variable $\mathrm{SiO}_{2}$ and $\mathrm{MgO}$ contents, strongly negative high field-strength element (HFSE, such as $\mathrm{Ta}, \mathrm{Nb}, \mathrm{Zr}$ and $\mathrm{Hf}$ ) anomalies on the normalized trace element diagram and show uniform $\left({ }^{87} \mathrm{Sr} /{ }^{86} \mathrm{Sr}\right)_{i}(0.7066-0.7076)$, $\varepsilon \mathrm{Nd}(\mathrm{t})(-2.50$ to -4.04$)$ and $\varepsilon \mathrm{Hf}(\mathrm{t})(+1.50$ to +7.50$)$. Their geochemical compositions are different from coeval (40-30 Ma) adakite-like rocks but comparable to coeval mafic enclaves and gabbros. We propose that Mingze monzodiorites were derived from partial melting of the lithospheric mantle, which previously metasomatized by the subducted Indian continental plate that probably subducted into the overlying mantle. The concurrency of the genetically related mafic enclaves and associated intermediate to mafic rocks implies the heterogeneity of the Lhasa lower crust.
\end{abstract}

Keywords: monzodiorite; Oligocene; Mingze; Southern Lhasa; geochemistry; geochronological; Sr-Nd-Hf isotope

\section{Introduction}

The Himalayan Tibetan Plateau is interpreted as the result of the Cenozoic collision between the Indian and Asian continents and subsequent continental subduction. It is considered as the most outstanding natural laboratory for studying the evolution of a continental collision orogenesis [1]. The Lhasa block is part of the Tibetan Plateau and an archetype of a Cenozoic collisional orogen related to the India-Asia collision [1-5]. Thus far, it has attracted much attention from numerous scholars.

The Mingze deposit is located in the Gangdese Kelu-Chongmuda metallogenic belts, which include the Chongmuda $\mathrm{Cu}$-Au deposit, Chengba $\mathrm{Cu}-\mathrm{Mo}$ deposit, Nuri Cu-Mo-Au deposit and Mingze $\mathrm{Cu}$ deposit [6]. Most of the previous studies were concentrated on the Chongmuda, Nuri and Chengba deposit, whereas the Mingze deposit was relatively understudied. Moreover, numerous previous geochronological works have been conducted, though few integrate the geochronologic data with petrogenesis studies [7-11]. The Mingze deposit is regionally near to the Chengba deposit ( 500 m), and people could have treated them as equivalent. In reality, their genesis and ore-associated intrusions are different as pointed out in this study.

In recent years, the Oligocene to the Miocene adakite-like rocks, which are mostly acid granitoid, have gotten plenty of attention, while the Late Eocene to the Oligocene intermediate-basic rocks have gotten far less interest $[2,6,7,9,12-16]$. In fact, the adakite-like rocks commonly contain a large number of mafic enclaves $[17,18]$, which possibly derived from the enriched lithospheric mantle. However, 
most of the mafic enclaves may have undergone a certain degree of evolution. Thus, it is hard to address the mantle enriching process through the studies of the mafic enclaves. Various models of the mantle enrichment have been proposed, including (1) metasomatized by the partial melting of the Neo-Tethyan Oceanic slab [2], (2) metasomatized by the Indian continental ancient sediments [19] and (3) metasomatized by the ancient crust of Central Lhasa [15]. The rocks formed as mantle-derived magma may provide an opportunity to address this issue. Furthermore, understanding the mechanism of the enrichment can also provide critical constraints on deep geodynamic processes under the Lhasa crust. However, the exact processes, such as whether the Indian continental crust was ever subducted into the Lhasa lithospheric mantle, are still unclear. On the other hand, the Eocene and Oligocene adakite-like rocks were interpreted as melts relative to the juvenile lower crust $[2,9,14]$. Therefore, it is worth exploring the relationship between the rocks relative to mantle and the coeval adakite-like rocks with mafic enclaves, as well as the reason for the formation of different types of rock.

In this study, we present geochronological, geochemical, and Sr-Nd-Hf isotopic data for the Mingze monzodiorites from southern Tibet. These data indicate that Mingze monzodiorites were emplaced in the Early Oligocene ( $\sim 31 \mathrm{Ma})$. Moreover, their geochemical and isotopic compositions are distinct from the contemporary adakite-like rocks, but comparable to the coeval mafic enclaves observed elsewhere in granitoids and the gabbros from south Tibet. Therefore, these data provide us an opportunity to better understand the age and petrogenesis of the Mingze area and to address the processes responsible for $\mathrm{Cu}-\mathrm{Mo}$ ore genesis.

\section{Geologic Background}

The Tibetan Plateau area is located in southwestern China (Figure 1a) and consists of four continental blocks. From south to north, they are the Himalaya, the Lhasa, the Qiangtang and the Songpan-Ganze blocks. The Lhasa block is bound by the Indus-Yarlung Tsangpo suture (IYTS) to the south and the Bangong-Nujiang suture (BNS) to the north [1]. 

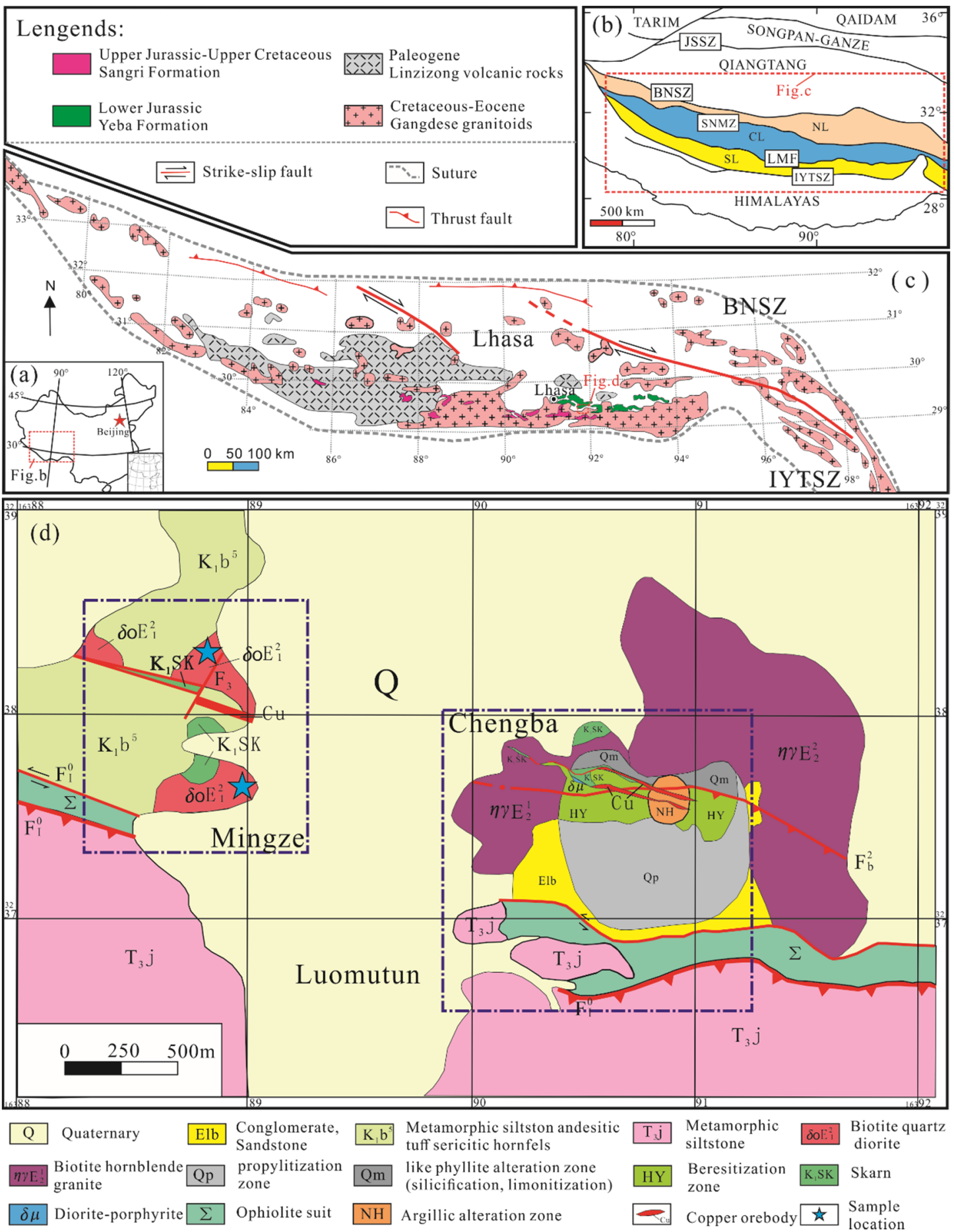

Figure 1. $(\mathbf{a}-\mathbf{c})$ Simplified geological map of the Tibetan Plateau and magmatic rocks in the Lhasa Block of southern Tibet (modify from [20] and references therein). (d) Geologic sketch map of the Mingze skarn Cu-Mo deposit (modified from No.2 Geological Institute of the China Metallurgical Geology Bureau (CMGB), 2011). Abbreviations: SL = Southern Lhasasub-block, CL = Central Lhasa sub-block, NL = Northern Lhasa sub-block, IYTSZ = Indus-Yarlung Tsangpo Suture Zone, LMF = Luobadui-Milashan Faul, SNMZ = Shiquan River-Nam Tso Mélange Zone, BNSZ = Bangong-Nujiang suture zone JSSZ = Jinsha suture zone. 
The Lhasa block has been separated into a northern, central and southern sub-block by the Shiquan River-Nam Tso Mélange zone (SNMZ) and Luobadui-Milashan fault (LMF), respectively (Figure 1b) [21].

The central Lhasa sub-block was once a microcontinent, which acted as a nucleus for the forming of the northern and southern blocks, and it has ancient basement rocks of Proterozoic and Archean ages [21]. The southern Lhasa sub-block contains widely distributed Mesozoic to Cenozoic intrusive and volcanic rocks (Figure 1c), which are composed of Upper Jurassic-Upper Cretaceous (136-93 Ma) Sangri Formation, lower Jurassic (190-174 Ma) Yeba formation, Paleogene Linzizong volcanic rocks and Cretaceous to Eocene Gangdese granitoids [20].

The Mingze area, which is located in Zedong county of Tibet, is within the southern Lhasa sub-block south of Yalung Tsangpo River. The Mingze ore block and Chengba ore block, named after their respective region, are also collectively named the Mingze deposit (Figure 1d) [6].

Zheng et al. [7] studied the Chengba granitoids, which were treated as Mingze rocks. The Mingze deposit is a typical skarn $\mathrm{Cu}$ deposit. The strata in the Mingze $\mathrm{Cu}$ deposit are mainly Triassic metamorphic siltstone, Cretaceous metamorphic siltstone, andesitic tuff and sericite hornfels. In this study, we focused on the petrogenesis of the monzodiorites from the area containing the Mingze $\mathrm{Cu}$ deposit.

\section{Samples and Methods}

Seven monzodiorite samples were collected from the least altered out crops of the Mingze $\mathrm{Cu}$ deposit. The Mingze monzodiorites show a typical massive structure and a medium-grained granular texture (Figure 2a,b). These monzodiorites are mainly composed of plagioclase (55-60\%), K-feldspar (15-20\%) and amphibole (10-15\%), with minor amounts of pyroxene, quartz, biotite, epidote and zircon (Figure 2c,d). Some minerals have suffered slight alteration, such as Fe oxides occurring along the margins of biotites. Plagioclase and K-feldspar crystals are euhedral or subhedral, whereas quartz crystals are subhedral grains and show rounded outlines. Amphibole grains are subhedral and their colors range from yellow to brown. All samples were analyzed for whole-rock major- and trace-element geochemistry, five of which were further analyzed for whole-rock Sr-Nd isotopes, and a sample was selected for laser-ablation inductively coupled plasma mass spectrometer (LA-ICP-MS) zircon U-Pb isotope and in situ Hf isotope analyses.

Zircon crystals separation was performed by Yuneng Rock Ore Sorting Technique Services Limited, who used conventional heavy liquid and magnetic separation techniques [22]. After separation, zircons for $\mathrm{U}-\mathrm{Pb}$ and $\mathrm{Lu}-\mathrm{Hf}$ isotopic detection were handpicked under a binocular microscope, and then mounted on epoxy resin discs.

The zircon U-Pb ages and cathodoluminescence (CL) images were provided by Wuhan Sample-Solution Analytical Technology Co., Ltd. The instrument for the zircon U-Pb isotopic detection used an Agilent 7700 LA-ICP-MS (Agilent, Santa Clara, CA, USA) and a $193 \mathrm{~nm}$ excimer laser ablation system. For this study, the ablation spot size was set to $32 \mu \mathrm{m}$, the ablated material was carried by He-Ar gas and the external standard used for U-Th-Pb isotopic ratios was the Harvard zircon 91500 [23]. Details of the analytical technique are provided by [24]. All the calculations and Concordia diagrams were completed using Isoplot 3.0 [25].

In situ Lu-Hf isotopic detections were conducted at the Geochemistry Lab of College of Earth sciences, Chengdu University of Technology, Chengdu, China by using a Finnigan Neptune Plus multicollector inductively coupled plasma mass spectrometer (MC-ICP-MS) and a Coherent GeoLasPro 193-nm laser-ablation system. The detections were performed on the same zircons, which had been analyzed for U-Pb ages. Details of the analytical technique are provided by [26].

The major and trace element analyses were performed by the ALS Chemex (ALS Limited, Guangzhou, China). The Samples for major element analyses were prepared with lithium borate-lithium nitrate solvent and detected by X-ray fluorescence (XRF) with detection limits of 
0.01 wt.\%. The Samples for trace element analyses were prepared with lithium borate solvent and detected by ICP-MS.
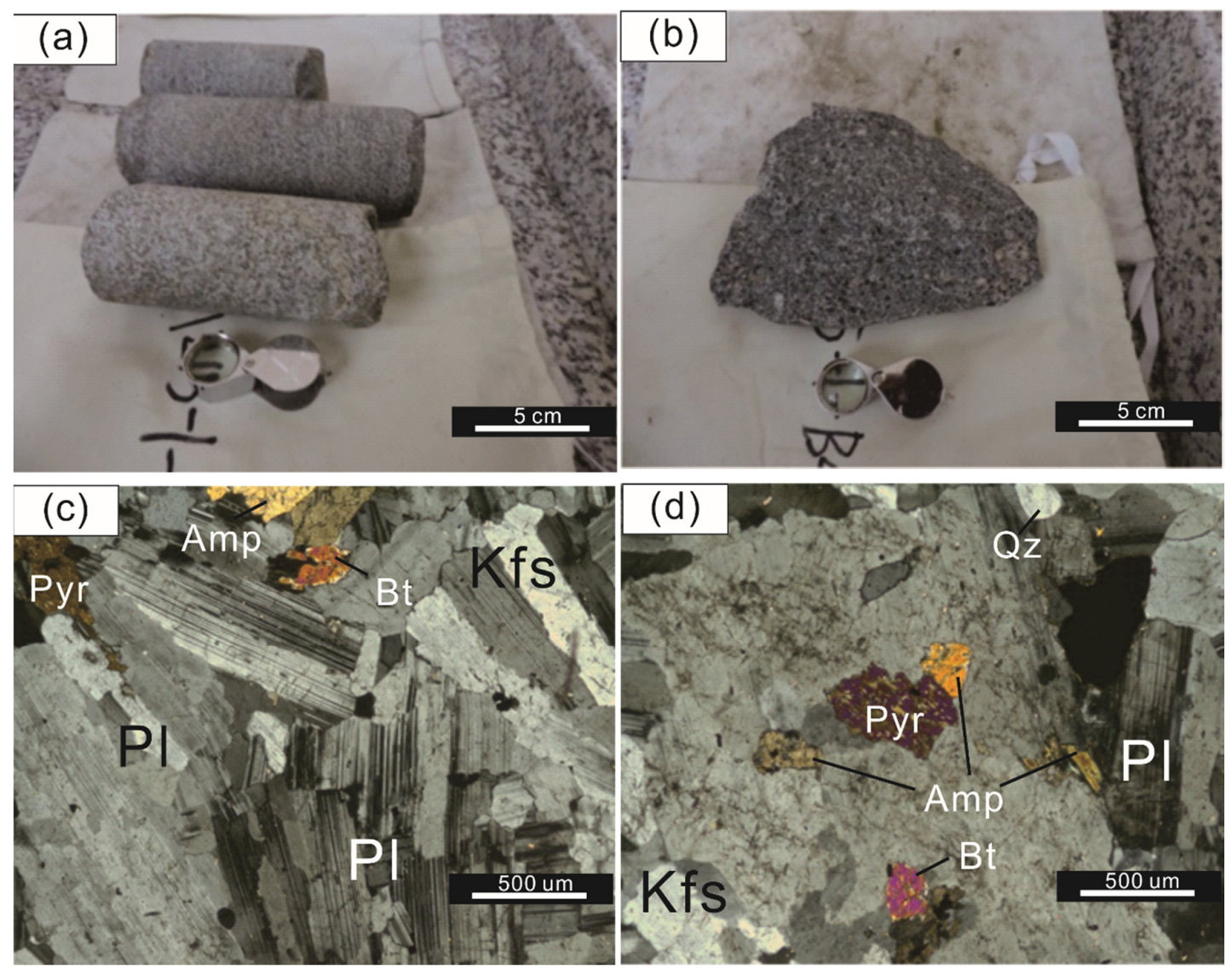

Figure 2. Photographs and photomicrographs of Mingze monzodiorites. (a) and (b): Two selected hand specimens of monzodiorite. (c) and (d): Mineral assemblage of monzodiorite. Abbreviations: Qz-quartz, Pl—plagioclase, Kfs—K-feldspar, Pyr—pyroxene, Amp—amphibole, Bt—biotite.

High precision isotopic ( $\mathrm{Sr}, \mathrm{Nd}$ ) measurements were carried out at Nanjing FocuMS Technology Co. Ltd (Nanjing, China). The Sr-, Nd- bearing elution were dried down and re-dissolved in $1.0 \mathrm{~mL}$ 2 wt.\% HNO3. Small aliquots of each were analyzed using an Agilent Technologies 7700x quadrupole ICP-MS (Hachioji, Tokyo, Japan) to determine the Sr, Nd abundances. Raw data of isotopic ratios were corrected for mass fractionation by normalizing to ${ }^{86} \mathrm{Sr} /{ }^{88} \mathrm{Sr}=0.1194$ for $\mathrm{Sr},{ }^{146} \mathrm{Nd} /{ }^{144} \mathrm{Nd}=0.7219$ for $\mathrm{Nd}$ with exponential law. International isotopic standards (NIST SRM 987 for Sr, JNdi-1 for Nd) were periodically analyzed to correct instrumental drift. Geochemical reference materials of USGS BCR-2, BHVO-2, AVG-2 and RGM-2 were used as quality control [27].

\section{Results}

\subsection{U-Pb Zircon Ages and Hf Isotopes}

The zircons separated from the sample MZ-12 were euhedral to subhedral crystal shapes exhibiting short prismatic forms. Most of the zircons were transparent and colorless, their average size is 60-150 $\mu \mathrm{m}$ and the length-to-width ratio is from 1:1 to 3:1, and show euhedral oscillatory zoning in cathodoluminescence (CL) images (Figure 3a). Zircon analyses from sample MZ-12 presented high Th and $\mathrm{U}$ contents (Th $=408-4692$ ppm, $\mathrm{U}=553-3925$ ppm, Table S1) and high ratios of Th/U (0.40-1.78). The features of CL images and the Th, $U$ contents indicated that all crystals have a magmatic origin [28-30]. 

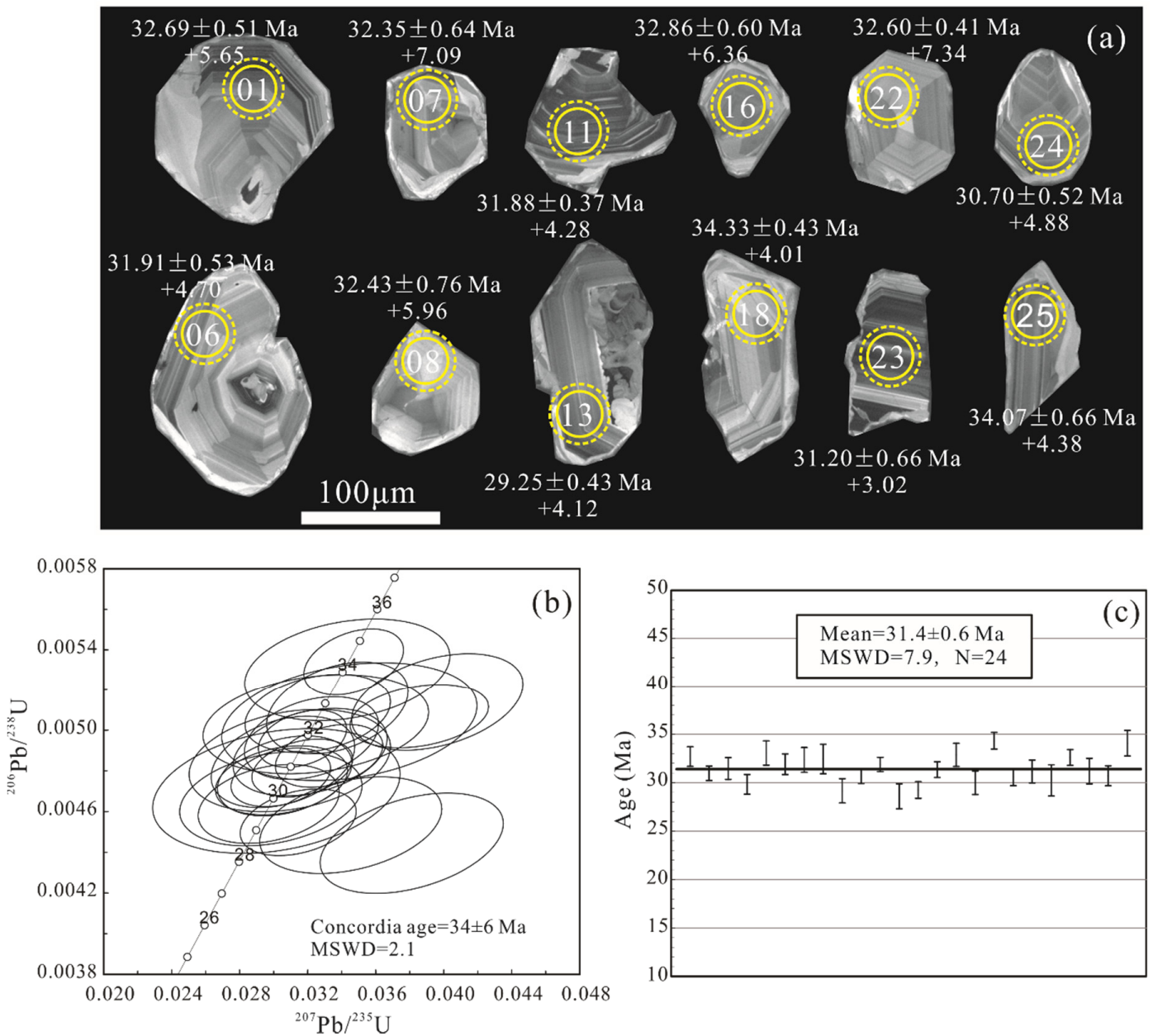

Figure 3. Representative CL images of zircons and concordia diagrams (a) and LA-ICP-MS U-Pb zircon Concordia diagrams and weighted ages of the Mingze monzodiorites $(\mathbf{b}, \mathbf{c})$.

Twenty-four spots were analyzed on these zircons, and all yielded concordant $206 \mathrm{~Pb} / 238 \mathrm{U}$ ages ranging from 28.6 Ma to 34.3 Ma (Table S1). These analyses give a weighted mean age of 31.4 $\pm 0.6 \mathrm{Ma}$ (MSWD $=7.9,1 \sigma$ for errors), which was identical to their concordant age of $34 \pm 6 \mathrm{Ma}$ (MSWD = 2.1) (Figure $3 b, c)$. Thus, the weighted mean age suggested that the monzodiorites were generated in the early Oligocene.

Twenty-one Hf analyses were corrected to the magmatic crystallization age of ca. $31.4 \mathrm{Ma}$, and yielded positive $\varepsilon \mathrm{Hf}(\mathrm{t})$ values of +1.50 to +7.50 . The values of ${ }^{176} \mathrm{Yb} /{ }^{177} \mathrm{Hf}$ and ${ }^{176} \mathrm{Lu} /{ }^{177} \mathrm{Hf}$ ranged from 0.007383 to 0.083558 and 0.000194 to 0.002016 , respectively (Table S2). Most values of ${ }^{176} \mathrm{Lu} /{ }^{177} \mathrm{Hf}$ were less than 0.002 , indicating that those zircons had not experienced a significant accumulation of radiogenic $\mathrm{Hf}$ after formation; thus, these ratios can be used as a representation of the Hf isotopic composition at the time of zircon formation [26]. The single-stage Hf model ages (TDM) were 403.71 to 642.61 Ma and the two-stage ages were 632.75 to $1013.62 \mathrm{Ma}$.

\subsection{Whole-Rock Geochemistry}

Whole-rock major and trace-element data for rocks from the Mingze monzodiorites are presented in Table S3. The Mingze monzodiorites are mainly shoshonitic and metaluminous (Figure 4b, A/CNK $=0.67-0.91$ ), with relatively low $\mathrm{SiO}_{2}$ contents (52.70-64.98 wt.\%), high $\mathrm{K}_{2} \mathrm{O}$ contents (3.06-4.29 wt.\%), relatively high $\mathrm{MgO}$ contents (1.86-5.76 wt.\%) and $\mathrm{Mg} \#$ values (48.39-65.57), ${ }^{\mathrm{T}} \mathrm{Fe}_{2} \mathrm{O}_{3}$ contents (3.94-7.78 wt.\%). 
All the samples from Mingze exhibit obvious right-dipping chondrite-normalized fractionated REE (rare earth element) patterns (Figure 5b) characterized by enrichment of LREE (light rare earth element), depletion of HREE (heavy rare earth element) [(La/Yb)N ratios (22.9-56.1)]. They also present relatively high values of total rare earth element (REE) values ranging from $228.93 \mathrm{ppm}$ to $343.05 \mathrm{ppm}$. There is a slight negative anomaly $(\delta \mathrm{Eu}=0.68-0.81)$. In the primitive mantle-normalized trace element variation diagram, these samples are enriched in large-ion lithophile elements (LILEs, such as $\mathrm{Rb}$, $\mathrm{Ba}, \mathrm{Th}, \mathrm{U}$ and $\mathrm{Sr}$ ) and are depleted in high field strength element (HFSE, such as $\mathrm{Ta}, \mathrm{Nb}, \mathrm{Zr}$ and $\mathrm{Hf}$ ) (Figure 5a).
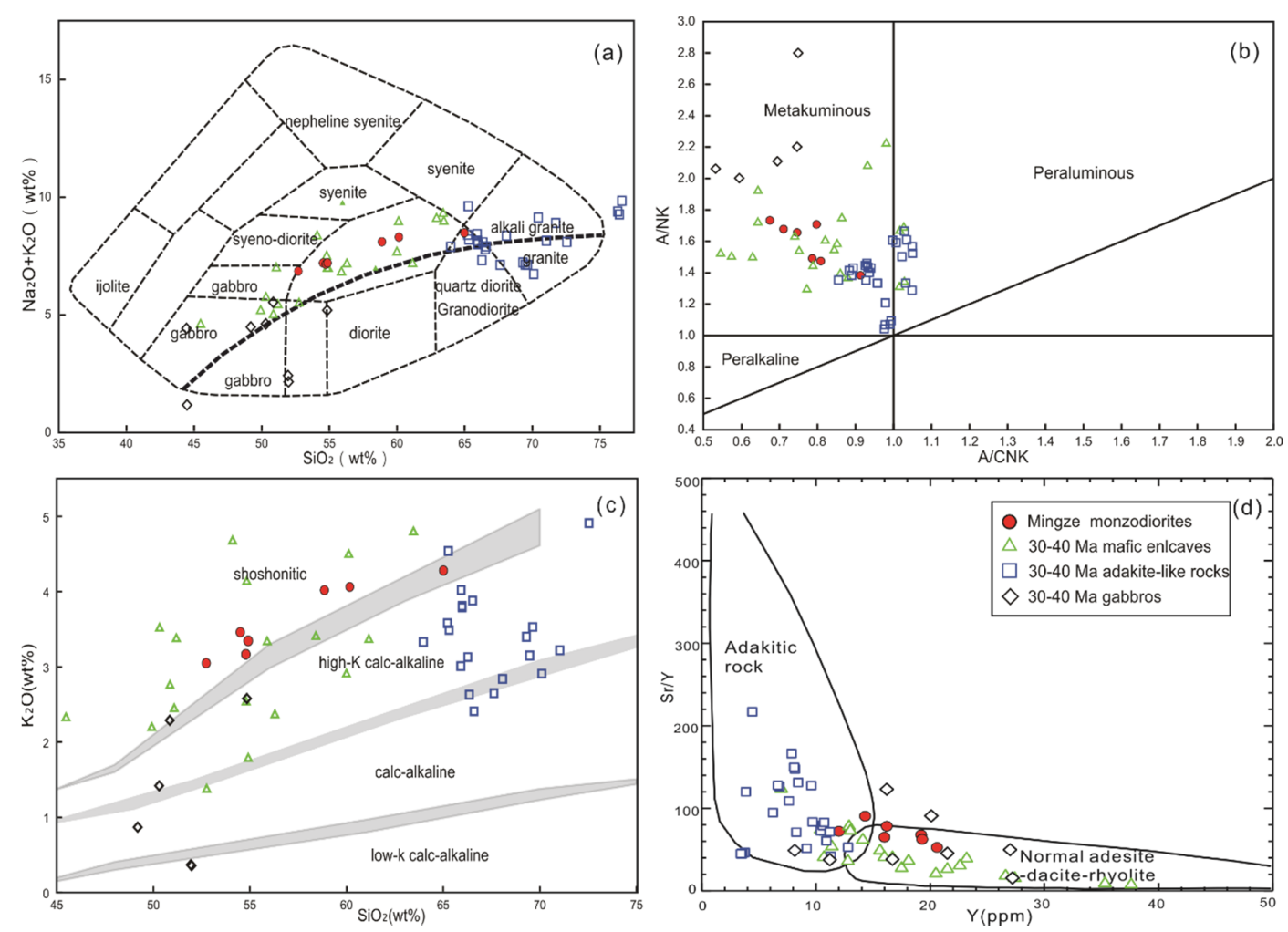

Figure 4. Variation diagrams for representative major and trace elements. (a) Total alkalis versus silica (TAS) diagram; (b) $\mathrm{SiO}_{2}$ vs. $\mathrm{K}_{2} \mathrm{O}$ diagram; (c) $\mathrm{K}_{2} \mathrm{O}-\mathrm{SiO}_{2}$ diagram; (d) $\mathrm{Sr} / \mathrm{Y}-\mathrm{Y}$ classification diagrams. The adakitic and arc calc-alkalic magmatic rocks from [31]. Data for comparison are from [7,15,16].
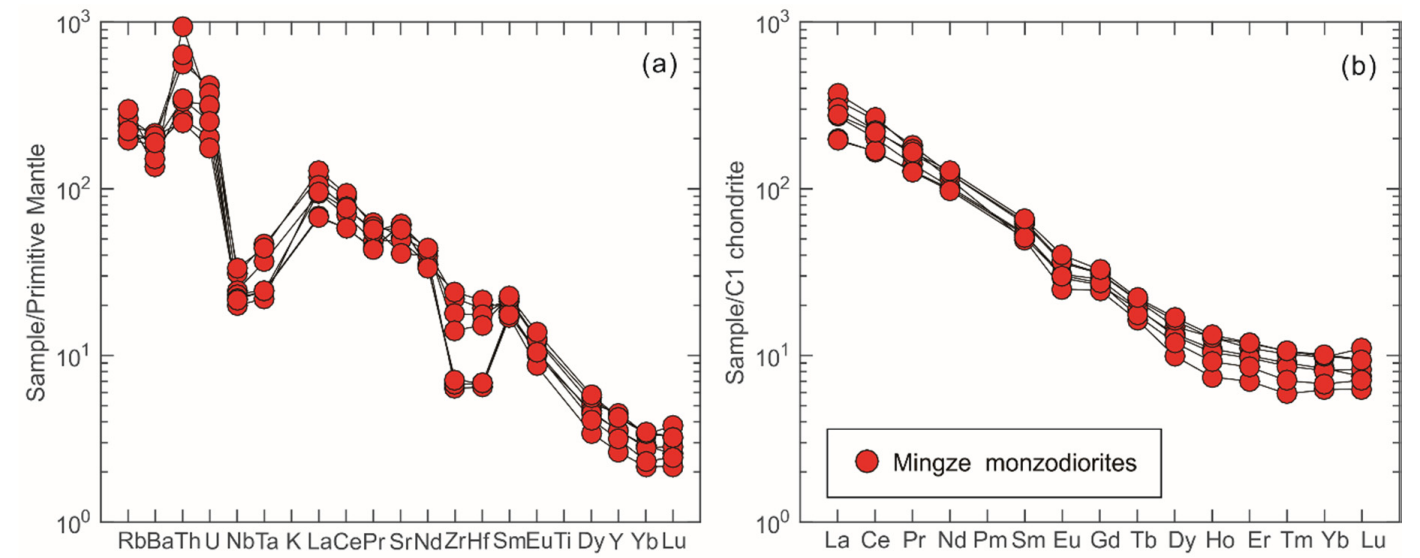

Figure 5. Primitive-mantle-normalized multi-element spider grams (a) and Chondrite-normalized rare earth element (REE) patterns (b) of the Mingze monzodiorites. Chondrite-normalized and primitive-mantle-normalized values are from [32]. 


\subsection{Whole-Rock Sr-Nd Isotopes}

Whole-rock Sr-Nd isotope data are presented in Table S3. All isotopic ratios were calculated using the zircon U-Pb age of 31.4 Ma. Samples have relatively low initial Sr isotopic ratios $\left[{ }^{87} \mathrm{Sr} /{ }^{86} \mathrm{Sr}\right)_{i}=$ $0.7066-0.7076]$ and low $\varepsilon \mathrm{Nd}(\mathrm{t})$ values of -4.04 to -2.49 (Figure 6). They have high $\mathrm{Nd}$ model ages $\left(\mathrm{T}_{\mathrm{DM}}(\mathrm{Nd})\right)$ ranging from $922 \mathrm{Ma}$ to $990 \mathrm{Ma}$.
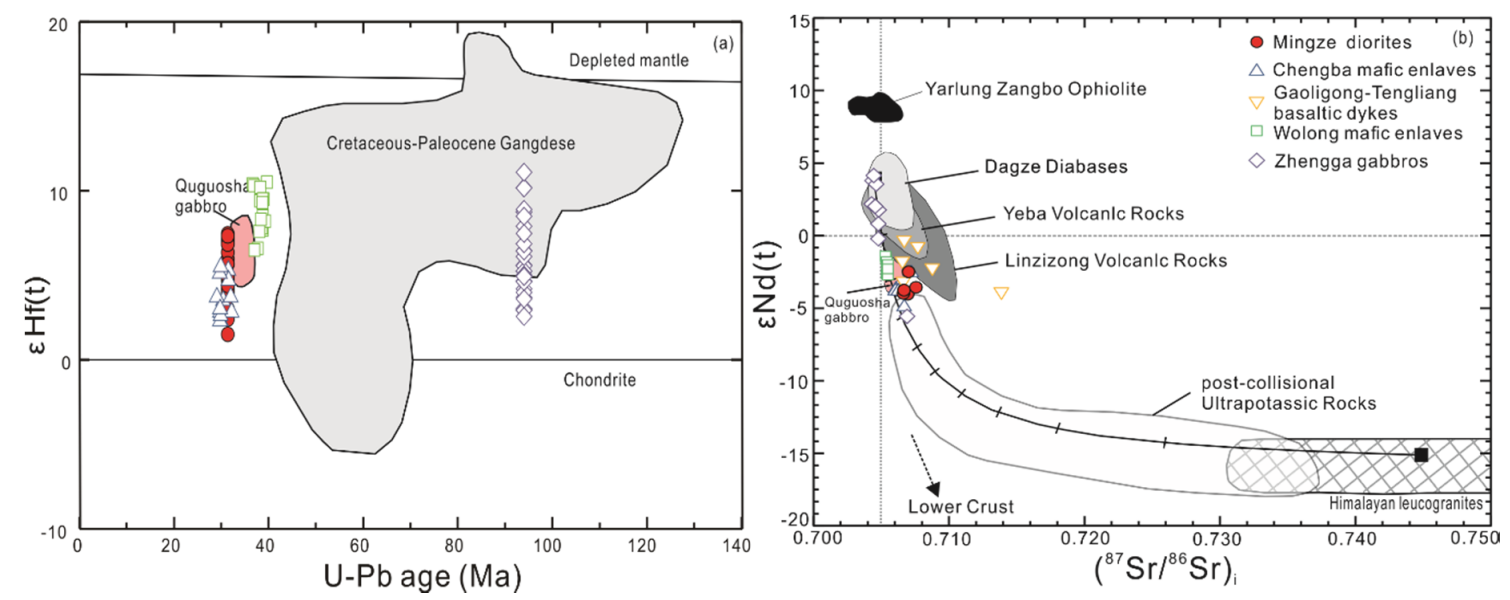

Figure 6. (a) $\varepsilon \mathrm{Hf}(\mathrm{t})$ values versus U-Pb zircon ages and (b) $\varepsilon \mathrm{Nd}(\mathrm{t})$ versus $\left({ }^{87} \mathrm{Sr} /{ }^{86} \mathrm{Sr}\right)_{i}$ diagrams (after [16]) for the Mingze monzodiorites, southern Tibet. Data sources are as follows: Cretaceous-Paleocene Gangdese are from [33]; Chengba mafic enclaves are from [7]; Wolong mafic enclaves are from [15]; Gaoligong-Tengliang basaltic dykes are from [34]; Zhengga gabbros are from [20]; IYTS (Indus-Yarlung Tsangpo Suture) ophiolites are from [35]; Yeba volcanic rocks are from [36]; Linzizong volcanic rocks are from [37] post-collisional ultrapotassic rocks are from [38]; Quguosha Gabbros are from [16]; Himalayan leucogranites are from [39]; data for the Dagze diabases are from [40].

\section{Discussion}

\subsection{Coeval Magmatism in the Mingze Region}

The relatively high $\mathrm{Th} / \mathrm{U}$ ratios (Table S1), as well as the well-developed oscillatory growth zoning in the zircons from the Mingze monzodiorites, indicate a magmatic origin. The weighted mean age $(31.4 \pm 0.6 \mathrm{Ma})$ of zircon ${ }^{206} \mathrm{~Pb} /{ }^{238} \mathrm{U}$ has relatively less error than the concordant age ( $\left.34 \pm 6 \mathrm{Ma}\right)$. These data are within the range reported by Zheng et al., [7], who suggested that the crystallization age of Chongmuda-Mingze granodiorites and monzogranites were $\sim 30 \mathrm{Ma}$. Mo et al. [8] reported that the crystallization age of Chongmuda monzogranites was $28 \mathrm{Ma}$. Several Zircon U-Pb age studies have been carried out in Cenozoic granitoids from the same area. For instance, Harrison et al. [41] and Chung et al. [9] reported ages of $\sim 30 \mathrm{Ma}$ from the Chengba granodiorites, and Jiang et al. [10] provided a $\sim 30 \mathrm{Ma}$ age for the Chongmuda quartz monzogranites. The above results are consistent with this study. Accordingly, we regard $\sim 31 \mathrm{Ma}$ as the crystallization time of Mingze monzodiorites, indicating that this intrusion of Mingze was emplaced in Early Oligocene.

\subsection{Petrogenesis of the Mingze Monzodiorites}

\subsubsection{Fractional Crystallization}

The major element compositions of the Mingze monzodiorites have a large range in composition (e.g., $\mathrm{SiO}_{2}, 52.70-64.98 \mathrm{wt} . \%$ ), relatively low $\mathrm{Mg} \#$ values (48.39-65.68) and $\mathrm{Cr}$ abundances (32-190 ppm) compared to typical mantle-derived magmas. The compositional ranges are compatible with the concepts of a combination of fractional crystallization and/or crystal accumulation [42]. This suggestion is supported by the oxides versus $\mathrm{SiO}_{2}$ and $\mathrm{MgO}$ diagrams (Figure $7 \mathrm{a}, \mathrm{c}, \mathrm{d}, \mathrm{f}$ and Figure $9 \mathrm{a}, \mathrm{b}, \mathrm{d}$ ), in which 
plots generally yield linear arrays, supporting the proposed fractional crystallization process to account for the geochemical trends.
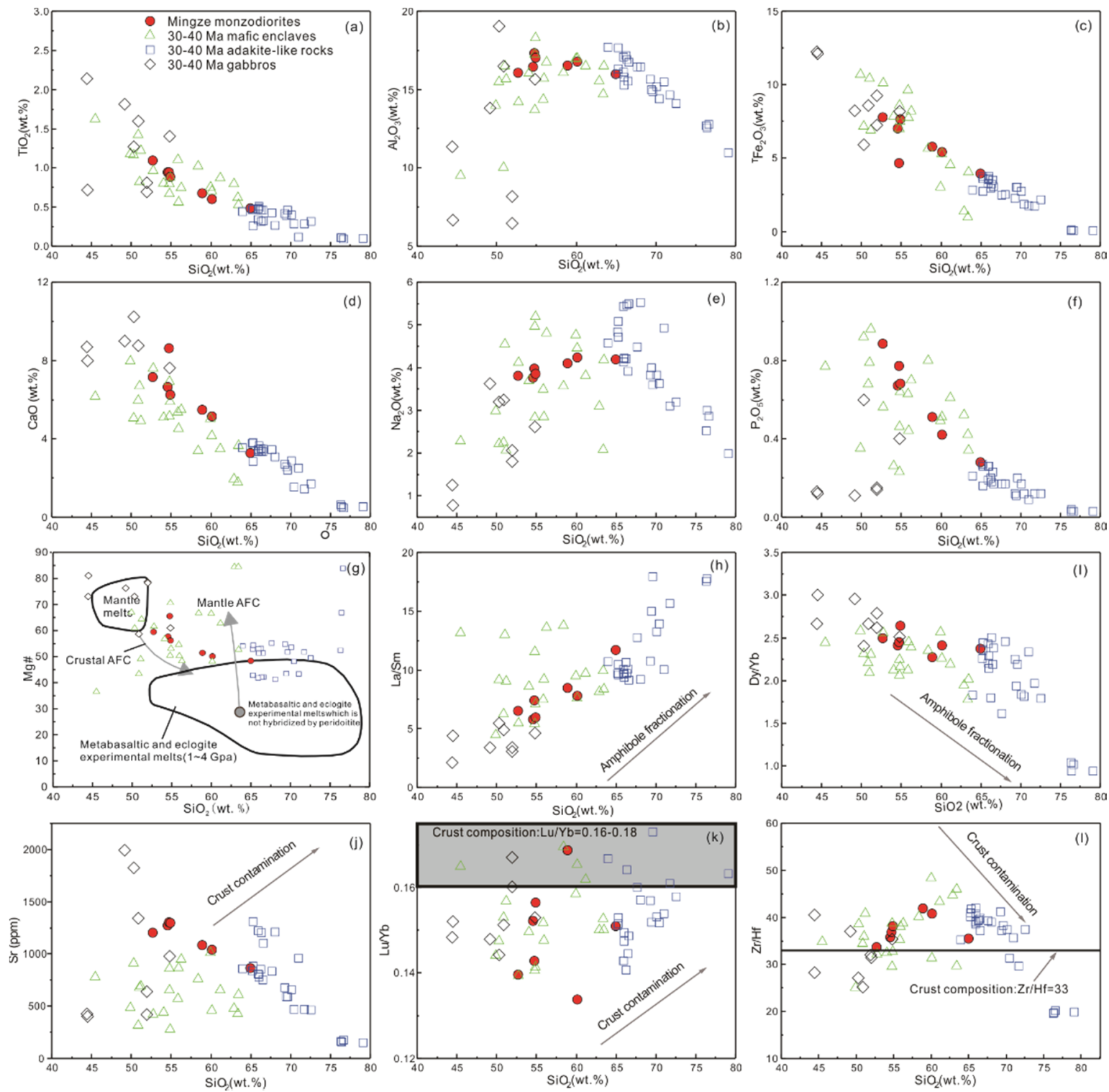

Figure 7. Selected elements and their ratios plot for the Mingze monzodiorites. $\mathrm{SiO}_{2}$ versus (a) $\mathrm{TiO}_{2}$, (b) $\mathrm{Al}_{2} \mathrm{O}_{3}$, (c) ${ }^{\mathrm{T}} \mathrm{Fe}_{2} \mathrm{O}_{3}$, (d) $\mathrm{CaO}$, (e) $\mathrm{Na}_{2} \mathrm{O}$, (f) $\mathrm{P}_{2} \mathrm{O}_{5}$, (g) Mg\#, (h) La/Sm ratio, (i) Dy/Yb ratio, (j) Sr, (k) $\mathrm{Lu} / \mathrm{Yb}$ ratio and (1) $\mathrm{Zr} / \mathrm{Hf}$ ratio. Modify after [43]. Data sources are the same as in Figure 4.

The trend of $\mathrm{La} / \mathrm{Sm}$ and $\mathrm{Dy} / \mathrm{Yb}$ ratios variations are relative to the concentration of $\mathrm{SiO}_{2}($ Figure $7 \mathrm{~h}, \mathrm{i})$ suggesting the possibility of amphibole fractionation [44]. Given that $\mathrm{Cr}$ is compatible in clinopyroxene, the relatively good linear relationship of $\mathrm{Cr}$ vs. $\mathrm{MgO}$ (Figure 9c), the low $\mathrm{CaO} / \mathrm{Al}_{2} \mathrm{O}_{3}$ ratios of $0.2-0.5$ and the good linear relationship of the $\mathrm{CaO} / \mathrm{Al}_{2} \mathrm{O}_{3}$ ratios vs. $\mathrm{MgO}$ abundances (Figure 9e) indicate that the clinopyroxene fractionation also played a significant role during the evolution of the magmatic system. Furthermore, plagioclase fractionation is supported by a slight negative Eu anomaly (Figure $5 b, \delta \mathrm{Eu}=$ 0.68-0.81). Neither layered structure in the outcrop nor textural evidence for crystal accumulation in thin sections have been observed. Together with the negative Eu anomaly, this precludes the possibility of crystal accumulation or that the initial source rock was relatively depleted in $\mathrm{Eu}^{2+}$. 


\subsubsection{Mechanism of Enriched Lithosphere Mantle}

The relatively low $\left({ }^{87} \mathrm{Sr} /{ }^{86} \mathrm{Sr}\right)_{i}(0.7077$ to 0.7076$)$ and negative $\varepsilon \mathrm{Nd}(\mathrm{t})(-2.49$ to -4.04$)$ of $\mathrm{Mingze}$ monzodiorites differ from the coeval Dagze mafic rocks $\left(40-38 \mathrm{Ma}, \varepsilon \mathrm{Nd}(\mathrm{t}),+5.2\right.$ to $+3.6 ;\left({ }^{87} \mathrm{Sr} / 86 \mathrm{Sr}\right)_{i}$, 0.7044-0.7062), which are $50 \mathrm{~km}$ east to Mingze and likely originated from an enriched asthenospheric mantle source [35]. The Yeba volcanic rocks $\left(\varepsilon \mathrm{Nd}(\mathrm{t}),+2.4\right.$ to $\left.+4.5 ;\left({ }^{87} \mathrm{Sr} /{ }^{86} \mathrm{Sr}\right)_{i}, 0.70427-0.70505\right)$ and the Linzizong volcanic rocks (e.g., ultrapotassic, $\varepsilon \mathrm{Nd}(\mathrm{t}),-6.1$ to $\left.+0.7 ;\left({ }^{87} \mathrm{Sr} /{ }^{86} \mathrm{Sr}\right)_{i}, 0.7058-0.7140\right)$ in southern Tibet with depleted mantle isotopic compositions [26,32] further indicate that the Mingze monzodiorites did not originate from a relatively depleted mantle source region. However, the isotopic signatures of Mingze monzodiorites are similar to the coeval basaltic dykes $(\varepsilon N d(t),-3.1$ to -0.3 ; $\left.\left({ }^{87} \mathrm{Sr} /{ }^{86} \mathrm{Sr}\right)_{i}, 0.7066-0.7088\right)$ in the Gaoligong-Tengliang belt of 40-42 Ma [29], as well as to $230 \mathrm{Ma}$ Chengba mafic enclaves $\left(\varepsilon \mathrm{Nd}(\mathrm{t}),-2.6\right.$ to $\left.-4.9 ;\left({ }^{87} \mathrm{Sr} /{ }^{86} \mathrm{Sr}\right)_{i}, 0.7060-0.7072\right)$ [25]. We suggest that the monzodiorites and mafic enclaves both originated from enriched lithospheric mantle beneath the Lhasa terrane. The coeval mafic enclaves in the Wolong granitoids $\left(\varepsilon N d(t),-2.7\right.$ to $-1.4 ;\left({ }^{87} \mathrm{Sr} /{ }^{86} \mathrm{Sr}\right)_{i}$, 0.7053-0.7055) of $\sim 38 \mathrm{Ma}[24]$ and coeval Quguosha gabbros ( 35 Ma, $\varepsilon \mathrm{Nd}(\mathrm{t}),-2.2$ to $-3.6 ;\left({ }^{87} \mathrm{Sr} /{ }^{86} \mathrm{Sr}\right)_{i}$, 0.7056-0.7058) [26] (Figure 6b), which are lithospheric mantle-derived, further indicate that the Mingze monzodiorites were derived from enriched lithospheric mantle beneath the Lhasa terrane.

Additionally, Mingze monzodiorites are characterized by relatively large content ranges of $\mathrm{MgO}$ (1.86-5.76 wt.\%), Mg\# (48.39-65.58), SiO2 (52.70-64.98 wt.\%) and ${ }^{\mathrm{T}} \mathrm{Fe}_{2} \mathrm{O}_{3}$ (3.94-7.78 wt.\%), which are not similar to typical crustal materials nor to mantle materials. Mingze monzodiorites are enriched in LILEs (e.g., Rb, Ba, Th and U) and LREE, and depleted in HFSEs (e.g., Ta, Nb, Zr and Hf) (Figure 5). These features collectively suggest that the origin of Mingze monzodiorites were derived as melts from an enriched mantle and/or mantle-derived mafic magmas that experienced crustal contamination. The following mechanisms can explain these geochemical features above: (1) magma mixing of mantleand crustal-derived members, (2) crustal contamination and (3) metasomatism by an older source material within subduction or thickened crustal delamination [45].

The $\mathrm{SiO}_{2}$ and $\mathrm{MgO}$ contents of Mingze monzodiorites are variable, and $\mathrm{Mg \#}$ values of Mingze monzodiorites are lower than the mantle melt but higher than the partial melting of crustal materials (Figure $7 \mathrm{~g}$ ). These features are consistent with those of the mantle mafic enclaves in adakite-like rocks, which were generated by the mixing of mantle- and crustal-derived magmas. However, relatively homogeneous Sr-Nd- Hf isotopic compositions $\left(\left({ }^{87} \mathrm{Sr} /{ }^{86} \mathrm{Sr}\right){ }_{i}, 0.7066-0.7076 ; \varepsilon \mathrm{Nd}(\mathrm{t}),-2.50\right.$ to $-4.04 ; \varepsilon \mathrm{Hf}(\mathrm{t})$, +1.50 to +7.50 ; Figure $6 \mathrm{a}, \mathrm{b}$ ) and the absence of linear trend between isotopic ratios and certain elements (e.g., $\mathrm{SiO}_{2}$ and $\mathrm{MgO}$ ) in the Mingze monzodiorites are inconsistent with the magma mixing model (Figure 8). Thus, the magma mixing model is not favored in this study.

Crustal contamination is almost inevitable during the ascent of mantle-derived melts through the continental crust [46]. In addition, crustal assimilation during magma ascent can cause an increase in $\left({ }^{87} \mathrm{Sr} /{ }^{86} \mathrm{Sr}\right)_{i}$ and a decrease in $\varepsilon \mathrm{Nd}(\mathrm{t})$ as the magmas are emplaced in the upper crust [47]. Therefore, we can compare major elements and radiogenic isotopes compositions to evaluate the effect of crustal contamination on basaltic rocks $[16,20]$. The data show that the $\left({ }^{87} \mathrm{Sr} /{ }^{86} \mathrm{Sr}\right)_{i}$ and $\varepsilon \mathrm{Nd}(\mathrm{t})$ do not vary with respect to $\mathrm{MgO}$ and $\mathrm{SiO}_{2}$ contents (Figure 8). This feature suggests limited crustal assimilation. The suggestion is further supported by the following evidence: (1) absence of a correlation between the $\mathrm{Sr}$ content, $\mathrm{Lu} / \mathrm{Yb}$ and $\mathrm{Zr} / \mathrm{Hf}$ ratios with $\mathrm{SiO}_{2}$ contents (Figure 7j-1); (2) the relatively homogenous zircon $\varepsilon \operatorname{Hf}(\mathrm{t})(+1.50$ to +7.46$)$, which argues for little or no crustal contamination involved in the parental magma [48]; (3) the negative Zr-Hf anomalies in the N-MORB-normalized trace element diagram (Figure 5a), which suggest the parent magmas might have not undergone crustal contamination, because crustal assimilation during emplacement would result in positive Zr and Hf anomalies [49]. Therefore, we conclude that crustal contamination played an insignificant role in the formation of the Mingze monzodiorites. 

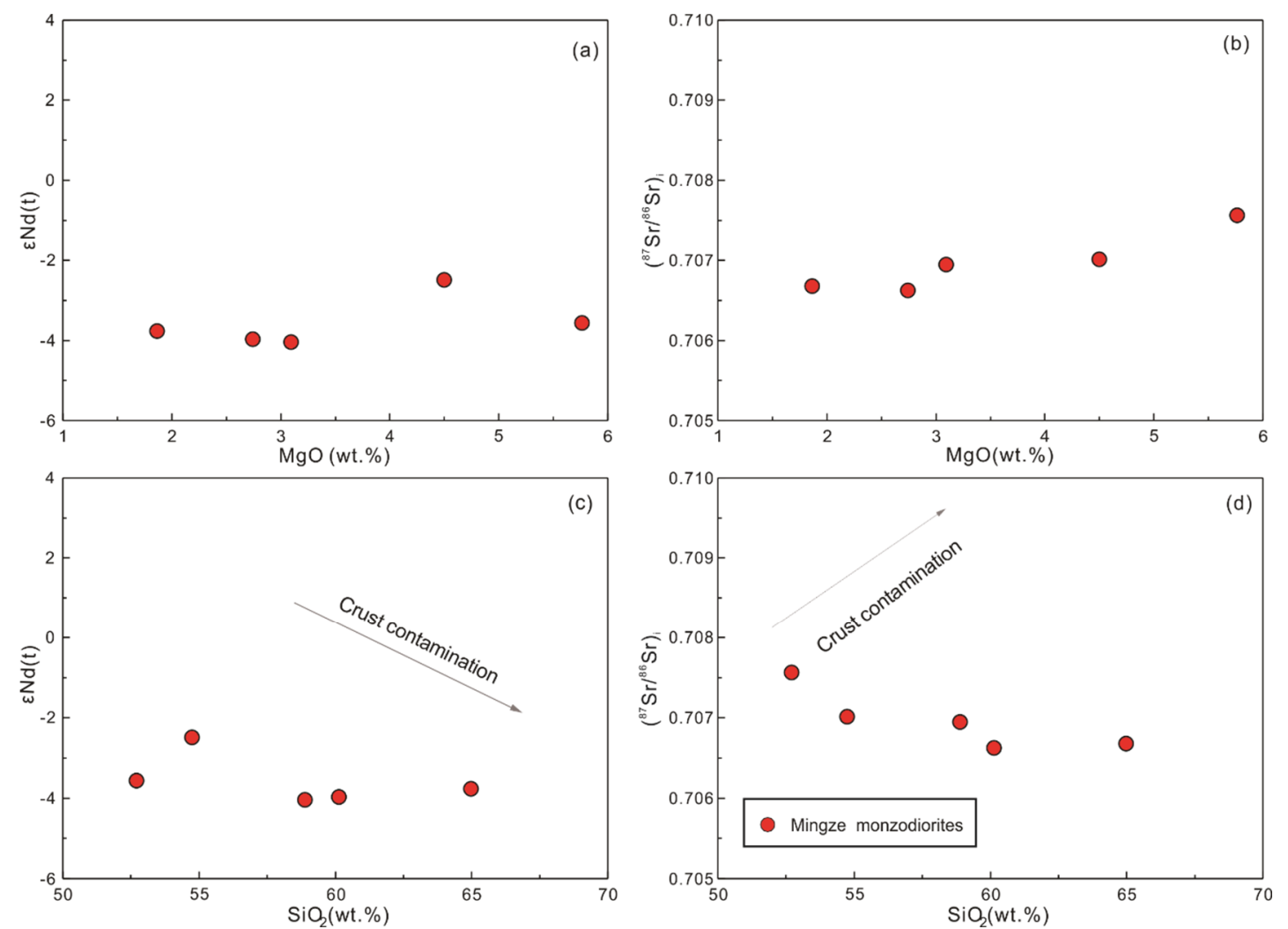

Figure 8. Plots of (a) $\varepsilon \mathrm{Nd}(\mathrm{t})$ versus $\mathrm{MgO}$, (b) $\left({ }^{87} \mathrm{Sr} /{ }^{88} \mathrm{Sr}\right)_{i}$ versus $\mathrm{MgO}$, (c) $\varepsilon \mathrm{Nd}(\mathrm{t})$ versus $\mathrm{SiO}_{2}$ and (d) $\left({ }^{87} \mathrm{Sr} /{ }^{88} \mathrm{Sr}\right)_{i}$ versus $\mathrm{SiO}_{2}$.

Metasomatism in lithospheric mantle could possibly have been triggered by both subduction and thickened crustal delamination [50,51]. However, the coeval Chengba-Chongmuda ( 30 Ma) and Linzi ( $28 \mathrm{Ma})$ adakitic intrusions have been interpreted as a partial melting of the lower crust that contained a certain amount of juvenile mantle-derived basaltic melts [7,52]. However, Mingze monzodiorites exhibited different major element compositions from those coeval adakite-like rocks (Figures 4, 7 and 9). This probably suggests that Mingze monzodiorites have different origin compared to those adakite-like rocks and have insignificant affinity to thickened crustal delamination (Figure 4d). We suggest, therefore, that the parent magma of Mingze monzodiorites was metasomatized by an older source material within a subduction setting.

The Mingze monzodiorites with relatively high $\mathrm{MgO}$ abundances (up to $5.76 \mathrm{wt.} \%$ ) and $\mathrm{Mg \#}$ (up to 65.58), low $\mathrm{SiO}_{2}(52.7-64.98 \mathrm{wt} . \%$ ) contents suggest that these monzodiorites could originally have been basaltic in composition. Oceanic basalts (i.e., mid-ocean ridge basalts [MORBs] and ocean island basalts [OIBs]) typically exhibit positive $\mathrm{Nb}$-Ta-Ti anomalies in primitive-mantle-normalized trace element diagrams [53]. However, all the Mingze samples exhibit significantly negative $\mathrm{Nb}-\mathrm{Ta}$ anomalies (Figure 5a). Moreover, Th/Ce (0.21-0.49) and Th/La (0.39-0.91) of the Mingze monzodiorites are much higher than mantle-derived magmas, with low Th/Ce (0.02-0.05) and Th/La ( 0.12) [32]. These features collectively suggest neither normal MORB- nor OIB-mantle material can be the source of Mingze monzodiorites. This suggestion is also supported by the diagram of $\varepsilon \mathrm{Nd}(\mathrm{t})$ versus $\varepsilon \mathrm{Hf}(\mathrm{t})$ (Figure 10a). 

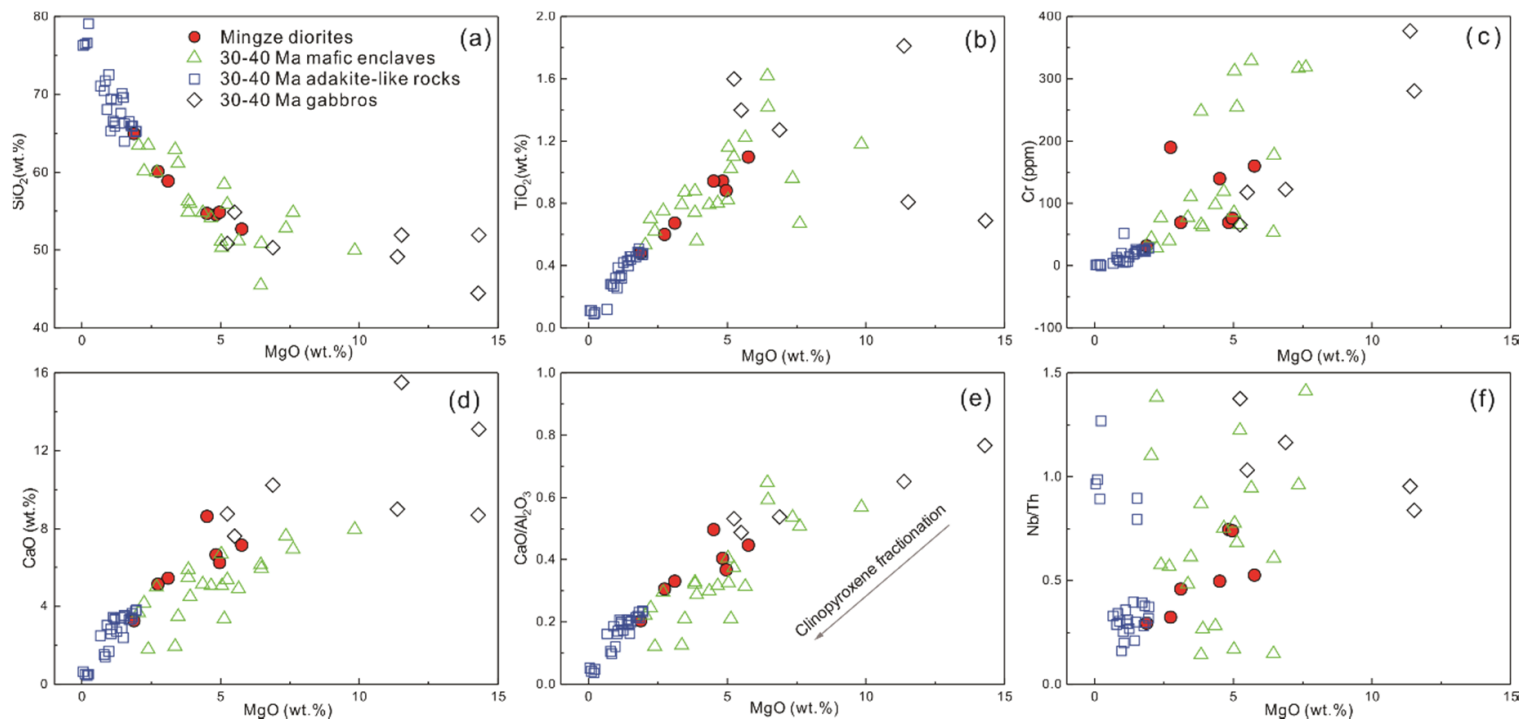

Figure 9. Representative major, trace elements plots of Mingze monzodiorites. (a) $\mathrm{MgO}$ versus $\mathrm{SiO}_{2}$; (b) $\mathrm{MgO}$ versus $\mathrm{TiO}_{2}$; (c) $\mathrm{MgO}$ versus $\mathrm{Cr}$; (d) $\mathrm{MgO}$ versus $\mathrm{CaO}$; (e) $\mathrm{MgO}$ versus $\mathrm{CaO} / \mathrm{Al}_{2} \mathrm{O}_{3}$; (f) $\mathrm{MgO}$ versus $\mathrm{Nb} / \mathrm{Th}$ ratio.

In the $\mathrm{Lu} / \mathrm{Yb}$ ratio and $\mathrm{Zr} / \mathrm{Hf}$ ratio versus $\mathrm{SiO}_{2}$ contents diagrams, some of the Mingze monzodiorites plotted in or near the field of crust composition (Figure $7 k, 1$ ) suggest their continental arc affinity. This suggestion is supported by $\varepsilon \mathrm{Nd}(\mathrm{t})$ versus $\varepsilon \mathrm{Hf}(\mathrm{t})$ plots that shift away from the mantle array (Figure 10a). Moreover, whole rock $\mathrm{Th}$ and $\mathrm{Nb}$ elements are useful indicators for crustal input [54]. Thus, when no crustal contamination was involved, the $\mathrm{Nb} / \mathrm{Yb}$ versus $\mathrm{Th} / \mathrm{Yb}$ ratio diagram is useful for distinguishing subduction-related and subduction-unrelated rocks [55]. Plots of Mingze monzodiorites in the diagram show continental arc affinity (Figure 10b).
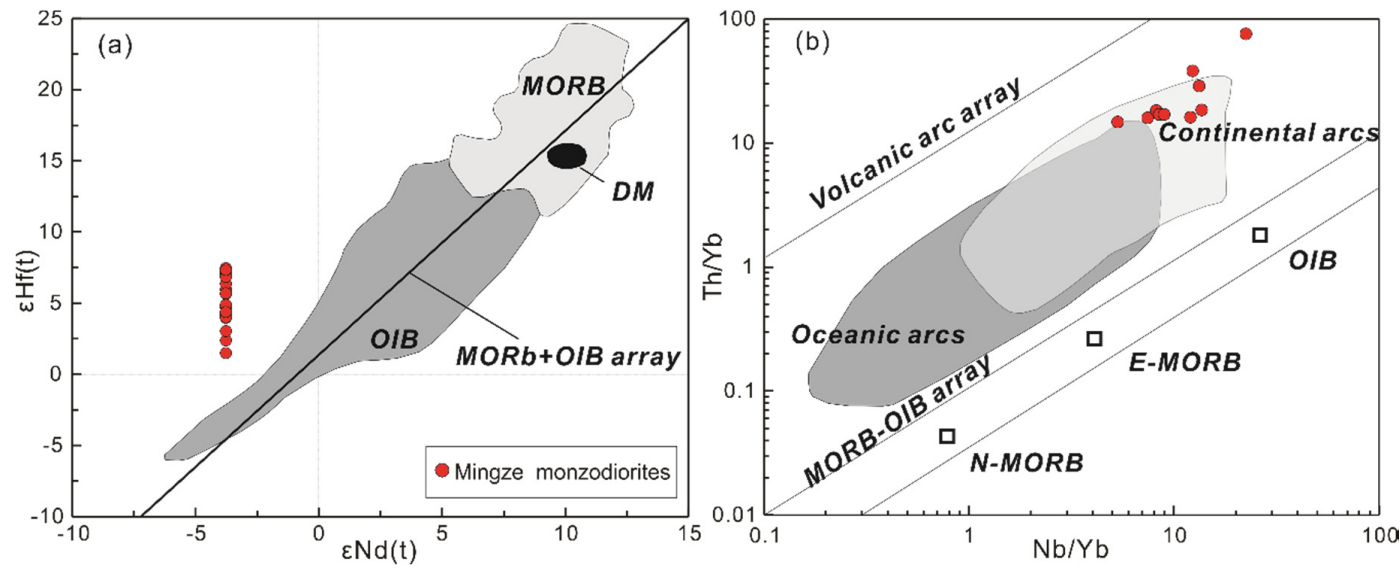

Figure 10. (a) $\varepsilon \mathrm{Nd}(\mathrm{t})$ versus $\varepsilon \mathrm{Hf}(\mathrm{t})$ (modify after [56]) and (b) $\mathrm{Th} / \mathrm{Yb}$ ratio versus $\mathrm{Nb} / \mathrm{Yb}$ ratio(modify after [45]) discrimination diagram for Mingze monzodiorites. MORB (mid-ocean ridge basalt) + OIB (ocean island basalt) array and fields for DM (depleted mantle), MORB and OIB are from [57].

\subsubsection{Origin of the Ancient Crustal Signature}

We propose that the parental magmas of the Mingze monzodiorites were derived from the enriched lithospheric mantle metasomatized by crustal materials in a subduction setting beneath the Lhasa terrane. However, there remains uncertainty about the origin of crustal materials. Previous work has proposed three potential metasomatic agents for forming enriched lithospheric mantle beneath the 
Lhasa terrane: (1) ancient crust within Central Lhasa block; (2) subducted Tethyan oceanic slab; and (3) subducted Indian continental materials ([16] and references therein).

It has been proposed that Early Eocene gabbros ( $53 \mathrm{Ma})$ from the Longge'er pluton in the western segment of the Gangdese batholith were derived from the partial melting of an enriched mantle wedge metasomatism by Central-Lhasa ancient crust-derived magmas [45]. However, the $\varepsilon \mathrm{Hf}(\mathrm{t})$ values of the Mingze monzodiorites $(\varepsilon \mathrm{Hf}(\mathrm{t})=+1.5$ to +7.5$)$ are significantly different from Longge'er gabbros $(\varepsilon \mathrm{Hf}(\mathrm{t})$ $=-1.2$ to +1.0$)$. Positive and negative zircon $\varepsilon \mathrm{Hf}(\mathrm{t})$ values are attributed to juvenile and ancient crustal sources, respectively [58]. The $\varepsilon \mathrm{Hf}(\mathrm{t})$ data indicates that fluids derived from the ancient Central-Lhasa crust were not the source of metasomatism. Moreover, previous work has demonstrated that the ancient crustal basement rocks of Proterozoic and Archean ages exist only in the central Lhasa sub-block and there is no known mechanism to bring the basement rocks of central sub-block to the mantle beneath the southern sub-block during the Cenozoic [21,59]. Thus, we posit that no Central-Lhasa ancient crust-derived materials were involved in the origin of Mingze monzodiorites.

Lithospheric mantle metasomatized by subducted oceanic slab is generally characterized by relatively high $\varepsilon \mathrm{Nd}(\mathrm{t})$, low $\left({ }^{87} \mathrm{Sr} /{ }^{86} \mathrm{Sr}\right)_{i}$ and HFSE enrichment [31,60], which is not observed in the Mingze monzodiorites. The Mingze monsodiorites have relatively low $\varepsilon \mathrm{Nd}(\mathrm{t})$, high $\left({ }^{87} \mathrm{Sr} /{ }^{86} \mathrm{Sr}\right)_{i}$ and depleted HFSE. Moreover, partial melting of subducted oceanic crust is a common formation mechanism of adakite [61,62], while Mingze monzodiorites exhibited no affinity to adakitic compositions (e.g., high Sr, low Y contents, Figure 4d). Thus, we rule out the possibility of a melt of subducted oceanic crust. Late Cretaceous ( $94 \mathrm{Ma}$ ) gabbros from Zhengga are suggested to originate from the mantle wedge metasomatized by sediment melts/fluids derived from the subducted Neo-Tethyan oceanic slab and characterized by relatively positive $\varepsilon \mathrm{Nd}(\mathrm{t})(-0.2$ to +4.1$)$ [20]. Their $\varepsilon \mathrm{Nd}(\mathrm{t})$ values are distinct from the Mingze monzodiorites (Figure $6 \mathrm{~b}$ ), which have negative $\varepsilon \mathrm{Nd}(\mathrm{t})(-4.04$ to -2.49$)$. Therefore, Neo-Tethyan oceanic slab can be excluded as a potential metasomatic agent.

The remaining candidate to explain the enriched mechanism of the Mingze monzodiorites magma source, therefore, is the metasomatism by subducted Indian continental materials. The $\varepsilon \mathrm{Nd}(\mathrm{t})$, $\left({ }^{87} \mathrm{Sr} /{ }^{86} \mathrm{Sr}\right)_{i}$, and $\varepsilon \mathrm{Hf}(\mathrm{t})$ values of the Mingze monzodiorites are quite similar to those of Quguosha gabbros, which were interpreted as the result of lithospheric mantle metasomatized by melts of Indian continental sediments (Figure $6 \mathrm{a}, \mathrm{b})$. As shown in the $\varepsilon \mathrm{Nd}(\mathrm{t})$ versus $\left({ }^{87} \mathrm{Sr} /{ }^{86} \mathrm{Sr}\right)_{i}$ diagram (Figure $6 \mathrm{~b}$ ), Mingze monzodiorites exhibit a limited range of values that fall on or near a mixing line between depleted mantle and the subducted Himalayan sediments represented by the Cenozoic Himalayan leucogranites. This indicates that such rocks can be interpreted to be the result of the depleted mantle that has been, to a certain degree, metasomatized by subducted Himalayan sediments. The isotopic compositions of the Mingze monzodiorites could have been generated by the mixing of approximately $15 \%$ Himalayan sediments and $85 \%$ mantle-derived components.

\subsection{Implications for Geodynamic Processes}

The addition of components derived from the subducted Indian continental crust could lead to the enrichment of the upper mantle below south Tibet [63]. In addition, as mentioned above, the parent magma of the Mingze monzodiorites is compatible with an interpretation of having incorporated approximately 10-15\% Himalayan-derived sediments. Moreover, Zheng et al., [7] suggested that the Indian continent subducted into the lithospheric mantle beneath the Lhasa block and accelerated the detachment of the Lhasa lithospheric root. Nábělek et al. [64] proposed that a ca. $15 \mathrm{~km}$ thick layer above the seismic Moho observed in the seismic cross-section is the subducted Indian lower continental crust. Taken together, the evidence suggests that the Indian continental crust had subducted into the lithospheric mantle beneath the Lhasa block before $~ 31 \mathrm{Ma}$.

The Mingze monzodiorites are similar in composition to those coeval mafic enclaves from Wolong and Chengba-Chongmuda, and to the gabbros from Quguosha in terms of geochemistry and petrogenesis (Figures 4, 7 and 9). Their crystallization ages were all about 40-30 Ma, implying that they originated from the same magmatic system that resulted from partial melts from an enriched 
lithospheric mantle. This system not only formed intermediate-basic intrusions, but also formed the mafic enclaves in granitoids. Chengba-Chongmuda and Wolong adakite-like rocks, which are the host rocks of the mafic enclaves, are interpreted as the results of partial melting of thickened low crust under the Lhasa terrane. The heat source for lower crust melting was proposed to be the intrusion of mantle-derived magma $[7,15]$. Thus, the presence of coeval mafic enclaves and intermediate-basic composition intrusions allows for two possibilities: (1) mantle-derived magma melted a part of the lower crust and mixed with it, then formed adakite-like rocks with mafic enclaves or (2) the mantle-derived magma did not melt the lower crust, yet formed as intermediate-basic intrusions. These possibilities suggest that the mantle-derived magma was heterothermal or that a different part the lower crust had a different melt point. The suggestion implies that the presence of coeval mafic enclaves and intermediate-basic intrusions is due to either the heterogeneity of the mantle-derived magma or the heterogeneity of the lower crust. It is hard to imagine heterogeneous mantle-derived magma forming similar rocks. In addition, the relatively homogeneous Sr-Nd-Hf (Figure 6) isotopic compositions of those rocks conflict with the heterogeneity of the mantle-derived magma. However, variable degrees of modification, by the underplated mantle-derived basaltic melts at the base of the Lhasa crust, can lead to heterogeneity $[21,65,66]$. Therefore, we proposed that the lower crust is highly heterogeneous in composition along the strike of the Lhasa terrane, and that the heterogeneity of the lower crust led to the concurrency of the intermediate-basic intrusions and adakite-like rocks with mafic enclaves.

\section{Conclusions}

1. The Mingze monzodiorites in southern Tibet were emplaced in the Early Oligocene ( 31 Ma).

2. The Mingze monzodiorites are the result of partial melting of the lithospheric mantle beneath the Lhasa terrane metasomatized by melts of Indian continental sediments.

3. The Indian continental crust was subducted into the lithospheric mantle beneath the Lhasa block prior to $\sim 30 \mathrm{Ma}$.

4. The concurrency of mafic enclaves and intermediate intrusions ( 40 to $30 \mathrm{Ma})$ indicates that the lower crust is heterogeneous along the strike of the Lhasa terrane.

Supplementary Materials: The following are available online at http://www.mdpi.com/2075-163X/10/4/301/s1, Table S1: LA-ICP-MS zircon U-Pb age data for the Mingze monzodiorites, Table S2: In-situ zircon Hf isotopic data of for the Mingze monzodiorites, Table S3: Major (wt.\%), trace element (ppm) and Sr-Nd isotopic composition of the Mingze monzodiorites.

Author Contributions: Wrote the paper, K.Z.; designed the experiments, Z.S. and F.Z.; took part in the data collection, R.L. All authors have read and agreed to the published version of the manuscript.

Funding: This study was funded by the China Geological Survey (grant no. 12120113095700, 121201010000150011-08).

Acknowledgments: The authors thank Fuhao Xiong for the zircon U-Pb dating. The authors are grateful to the critical and thoughtful comments from the editors and the anonymous reviewers, which profoundly enhanced the quality of this manuscript.

Conflicts of Interest: The authors declare no conflict of interest.

\section{References}

1. Yin, A.; Harrison, T.M. Geologic evolution of the Himalayan-Tibetan orogen. Annu. Rev. Earth Planet. Sci. 2000, 28, 211-280. [CrossRef]

2. Mo, X.X.; Hou, Z.Q.; Niu, Y.L.; Dong, G.C.; Qu, X.M.; Zhao, Z.D.; Yang, Z.M. Mantle contributions to crustal thickening during continental collision: Evidence from Cenozoic igneous rocks in southern Tibet. Lithos 2007, 96, 225-242. [CrossRef]

3. Mo, X.X.; Niu, Y.L.; Dong, G.C.; Zhao, Z.D.; Hou, Z.Q.; Zhou, S.; Ke, S. Contribution of syncollisional felsic magmatism to continental crust growth: A case study of the Paleogene Linzizong volcanic Succession in southern Tibet. Chem. Geol. 2008, 250, 49-67. [CrossRef] 
4. Aitchison, J.C.; Xia, X.P.; Baxter, A.T.; Ali, J.R. Detrital zircon U-Pb ages along the Yarlung-Tsangpo suture zone, Tibet: Implications for oblique convergence and collision between India and Asia. Gondwana Res. 2011, 20, 691-709. [CrossRef]

5. Xia, L.Q.; Li, X.M.; Ma, Z.P.; Xu, X.Y.; Xia, Z.C. Cenozoic volcanism and tectonic evolution of the Tibetan plateau. Gondwana Res. 2011, 19, 850-866. [CrossRef]

6. Sun, X.; Zheng, Y.Y.; Wu, S.; You, Z.M.; Wu, X.; Li, M.; Zhou, T.C.; Dong, J. Mineralization age and petrogenesis of associated intrusions in the Mingze-Chengba porphyry-skarn Mo-Cu deposit, Gangdese. Acta Petrol. Sin. 2013, 29, 1392-1406. (In Chinese)

7. Zheng, Y.C.; Hou, Z.Q.; Li, W.; Liang, W.; Huang, K.X.; Li, Q.Y.; Sun, Q.Z.; Fu, Q.; Zhang, S. Petrogenesis and Geological Implications of the Oligocene Chongmuda-Mingze Adakite-Like Intrusions and Their Mafic Enclaves, Southern Tibet. J. Geol. 2012, 120, 647-669. [CrossRef]

8. Mo, J.H.; Liang, H.Y.; Yu, H.X.; Chen, Y.; Sun, W.D. Zircon U-Pb age of biotite hornblende monzonitic granite for Chongmuda Cu-Au (Mo) deposit in Gangdese belt, Xizang, China and its implications. Geochemica 2008, 3, 206-212.

9. Chung, S.L.; Chu, M.F.; Ji, J.Q.; O’Reilly, S.Y.; Pearson, N.J.; Liu, D.Y.; Lee, T.Y.; Lo, C.H. The nature and timing of crustal thickening in southern Tibet: Geochemical and zircon Hf isotopic constraints from post collisional adakites. Tectonophysics 2009, 477, 36-48. [CrossRef]

10. Jiang, Z.Q.; Wang, Q.; Wyman, D.A.; Tang, G.J.; Jia, X.H.; Yang, Y.H.; Yu, H.X. Origin of 30 Ma Chongmuda adakitic intrusive rocks in southern Gangdese region, southern Tebit: Partial melting of the northward subducted Indian continent crust? Geochemica 2011, 40, 126-146. (In Chinese)

11. Chen, L.; Qin, K.Z.; Li, G.M.; Li, J.X.; Xiao, B.; Zhao, J.X.; Fan, X. Zircon U-Pb ages, geochemistry, and $\mathrm{Sr}-\mathrm{Nd}-\mathrm{Pb}-\mathrm{Hf}$ isotopes of the Nuri intrusive rocks in the Gangdese area, southern Tibet: Constraints on timing, petrogenesis, and tectonic transformation. Lithos 2015, 212, 379-396. [CrossRef]

12. Williams, H.; Turner, S.; Kelley, S.; Harris, N. Age and composition of dikes in Southern Tibet: New constraints on the timing of east-west extension and its relationship to postcollisional volcanism. Geology 2001, 29, 339-342. [CrossRef]

13. Chung, S.L.; Liu, D.Y.; Ji, J.Q.; Chu, M.F.; Lee, H.Y.; Wen, D.J.; Lo, C.H.; Lee, T.Y.; Qian, Q.; Zhang, Q. Adakites from continental collision zones: Melting of thickened lower crust beneath southern Tibet. Geology 2003, 31, 1021-1024. [CrossRef]

14. Hou, Z.Q.; Gao, Y.F.; Qu, X.M.; Rui, Z.Y.; Mo, X.X. Origin of adakitic intrusives generated during mid-Miocene east-west extension in southern Tibet. Earth Planet. Sci. Lett. 2004, 220, 139-155. [CrossRef]

15. Guan, Q.; Zhu, D.C.; Zhao, Z.D.; Dong, G.C.; Zhang, L.L.; Li, X.W.; Liu, M.; Mo, X.X.; Liu, Y.S.; Yuan, H.L. Crustal thickening prior to $38 \mathrm{Ma}$ in southern Tibet: Evidence from lower crust-derived adakitic magmatism in the Gangdese Batholith. Gondwana Res. 2012, 21, 88-99. [CrossRef]

16. Ma, L.; Wang, Q.; Li, Z.X.; Wyman, D.A.; Yang, J.H.; Jiang, Z.Q.; Liu, Y.S.; Gou, G.N.; Guo, H.F. Subduction of Indian continent beneath southern Tibet in the latest Eocene (similar to $35 \mathrm{Ma}$ ): Insights from the Quguosha gabbros in southern Lhasa block. Gondwana Res. 2017, 41,77-92. [CrossRef]

17. Hou, Z.Q.; Cook, N.J. Metallogenesis of the Tibetan collisional orogen: A review and introduction to the special issue. Ore Geol. Rev. 2009, 36, 2-24. [CrossRef]

18. Yang, Z.M.; Hou, Z.Q.; White, N.C.; Chang, Z.S.; Li, Z.Q.; Song, Y.C. Geology of the post-collisional porphyry copper-molybdenum deposit at Qulong, Tibet. Ore Geol. Rev. 2009, 36, 133-159. [CrossRef]

19. Mo, X.X.; Dong, G.C.; Zhao, Z.D.; Zhu, D.C.; Zhou, S.; Niu, Y.L. Mantle Input to the Crust in Southern Gangdese, Tibet, during the Cenozoic: Zircon Hf Isotopic Evidence. J. Earth Sci. 2009, 20, 241-249. [CrossRef]

20. Ma, L.; Wang, Q.; Wyman, D.A.; Jiang, Z.Q.; Yang, J.H.; Li, Q.L.; Gou, G.N.; Guo, H.F. Late Cretaceous crustal growth in the Gangdese area, southern Tibet: Petrological and Sr-Nd-Hf-O isotopic evidence from Zhengga diorite-gabbro. Chem. Geol. 2013, 349, 54-70. [CrossRef]

21. Zhu, D.C.; Zhao, Z.D.; Niu, Y.L.; Mo, X.X.; Chung, S.L.; Hou, Z.Q.; Wang, L.Q.; Wu, F.Y. The Lhasa Terrane: Record of a microcontinent and its histories of drift and growth. Earth Planet. Sci. Lett. 2011, 301, 241-255. [CrossRef]

22. AutKeith, N.S.; Richard, A.S. An investigation of artificial biasing in detrital zircon U-Pb geochronology due to magnetic separation in sample preparation. Geochim. Cosmochim. Acta 2002, 66, 2379-2397.

23. Wiedenbeck, M.; Alle, P.; Corfu, F. Three Natural Zircon Standards for U-Th-Pb, Lu-Hf, Trace Element and REE Analyses. Geostand. Geoanal. Res. 1995, 19, 1-23. [CrossRef] 
24. Yongsheng, L.; Zhaochu, H.; Shan, G.; Günther, D.; Juan, X.; Changgui, G.; Haihong, C. In situ analysis of major and trace elements of anhydrous minerals by LA-ICPMS without applying an internal standard. Chem. Geol. 2008, 257, 34-43.

25. Ludwig, K.R. Berkeley Geochronology Center; Berkeley Geochronology Center: Berkeley, CA, USA, 2003.

26. Wu, F.Y.; Yang, Y.H.; Xie, L.W.; Yang, J.H.; Xu, P. Hf isotopic compositions of the standard zircons and baddeleyites used in U-Pb geochronology. Chem. Geol. 2006, 234, 105-126. [CrossRef]

27. Weis, D.; Kieffer, B.; Maerschalk, C.; Barling, J.; de Jong, J.; Williams, G.A.; Hanano, D.; Pretorius, W.; Mattielli, N.; Scoates, J.S.; et al. High-precision isotopic characterization of USGS reference materials by TIMS and MC-ICP-MS. Geochem. Geophys. Geosyst. 2006, 7, Q08006. [CrossRef]

28. Corfu, F.; Hanchar, J.M.; Hoskin, P.W.O.; Kinny, P. Atlas of zircon textures. Rev. Mineral. Geochem. 2003, 53, 469-500. [CrossRef]

29. Hoskin, P.W.O.; Schaltegger, U. The composition of zircon and igneous and metamorphic petrogenesis. Rev. Mineral. Geochem. 2003, 53, 27-62. [CrossRef]

30. Wu, Y.B.; Zheng, Y.F. Genetic mineralogy of zircon and its constraints on the interpretation of U-Pb age. Chin. Sci. Bull. 2003, 49, 1589-1604. (In Chinese)

31. Defant, M.J.; Drummond, M.S. Derivation of somemodern arc magmas by melting of young subducted lithosphere. Nature 1990, 347, 662-665. [CrossRef]

32. Sun, S.S.; McDonough, W.F. Chemical and isotopic systematics of oceanic basalts: Implications for mantle composition and processes. Geol. Soc. Lond. Spec. Publ. 1989, 42, 313-345. [CrossRef]

33. Chu, M.F.; Chung, S.L.; O’Reilly, S.Y.; Pearson, N.J.; Wu, F.Y.; Li, X.H.; Liu, D.Y.; Ji, J.Q.; Chu, C.H.; Lee, H.Y. India's hidden inputs to Tibetan orogeny revealed by Hf isotopes of Transhimalayan zircons and host rocks. Earth Planet. Sci. Lett. 2011, 307, 479-486. [CrossRef]

34. Xu, Y.G.; Lan, J.B.; Yang, Q.J.; Huang, X.L.; Qiu, H.N. Eocene break-off of the Neo-Tethyan slab as inferred from intraplate-type mafic dykes in the Gaoligong orogenic belt, eastern Tibet. Chem. Geol. 2008, 255, 439-453. [CrossRef]

35. Mahoney, J.J.; Frei, R.; Tejada, M.; Mo, X.; Leat, P.; Nägler, T. Tracing the Indian Ocean mantle domain through time: Isotopic results from old West Indian, East Tethyan, and South Pacific seafloor. J. Petrol. 1998, 39, 1285-1306. [CrossRef]

36. Wei, Y.Q.; Zhao, Z.D.; Niu, Y.L.; Zhu, D.C.; Liu, D.; Wang, Q.; Hou, Z.Q.; Mo, X.X.; Wei, J.C. Geochronology and geochemistry of the Early Jurassic Yeba Formation volcanic rocks in southern Tibet: Initiation of back-arc rifting and crustal accretion in the southern Lhasa Terrane. Lithos 2017, 278, 477-490. [CrossRef]

37. Lee, H.Y.; Chung, S.L.; Ji, J.; Qian, Q.; Gallet, S.; Lo, C.H.; Lee, T.Y.; Zhang, Q. Geochemical and Sr-Nd isotopic constraints on the genesis of the Cenozoic Linzizong volcanic successions, southern Tibet. J. Asian Earth Sci. 2012, 53, 96-114. [CrossRef]

38. Zhao, Z.D.; Mo, X.X.; Dilek, Y.; Niu, Y.L.; DePaolo, D.J.; Robinson, P.; Zhu, D.C.; Sun, C.G.; Dong, G.C.; Zhou, S.; et al. Geochemical and Sr-Nd-Pb-O isotopic compositions of the post-collisional ultrapotassic magmatism in SW Tibet: Petrogenesis and implications for India intra-continental subduction beneath southern Tibet. Lithos 2009, 113, 190-212. [CrossRef]

39. Guo, Z.F.; Wilson, M. The Himalayan leucogranites: Constraints on the nature of their crustal source region and geodynamic setting. Gondwana Res. 2012, 22, 360-376. [CrossRef]

40. Ma, L.; Wang, Q.; Wyman, D.A.; Jiang, Z.Q.; Wu, F.Y.; Li, X.H.; Yang, J.H.; Gou, G.N.; Guo, H.F. Late Cretaceous back-arc extension and arc system evolution in the Gangdese area, southern Tibet: Geochronological, petrological, and Sr-Nd-Hf-O isotopic evidence from Dagze diabases. J. Geophys. Res. Solid Earth 2015, 120, 6159-6181. [CrossRef]

41. Harrison, T.M.; Yin, A.; Grove, M.; Lovera, O.M.; Ryerson, F.J.; Zhou, X.H. The Zedong Window: A record of superposed Tertiary convergence in southeastern Tibet. J. Geophys. Res. Solid Earth 2000, 105, 19211-19230. [CrossRef]

42. Perfit, M.R.; Gust, D.A.; Bence, A.E.; Arculus, R.J.; Taylor, S.R. Chemical Characteristics of Island-Arc Basalts-Implications for Mantle Sources. Chem. Geol. 1980, 30, 227-256. [CrossRef]

43. Zhao, X.; Fu, L.B.; Wei, J.H.; Bagas, L.; Santosh, M.; Liu, Y.; Zhang, D.H.; Zhou, H.Z. Late Permian back-arc extension of the eastern Paleo-Tethys Ocean: Evidence from the East Kunlun Orogen, Northern Tibetan Plateau. Lithos 2019, 340, 34-48. [CrossRef] 
44. Davidson, J.; Turner, S.; Handley, H.; MacPherson, C.; Dosseto, A. Amphibole "sponge" in arc crust? Geology 2007, 35, 787. [CrossRef]

45. Zhang, Y.H.; Cao, H.W.; Hollis, S.P.; Tang, L.; Xu, M.; Jiang, J.S.; Gao, S.B.; Wang, Y.S. Geochronology, geochemistry and $\mathrm{Sr}-\mathrm{Nd}-\mathrm{Pb}-\mathrm{Hf}$ isotopes of the Early Paleogene gabbro and granite from Central Lhasa, southern Tibet: Petrogenesis and tectonic implications. Int. Geol. Rev. 2019, 61, 868-894. [CrossRef]

46. Castillo, P.R.; Janney, P.E.; Solidum, R.U. Petrology and geochemistry of Camiguin Island, southern Philippines: Insights to the source of adakites and other lavas in a complex arc setting. Contrib. Mineral. Petrol. 1999, 134, 33-51. [CrossRef]

47. Rogers, N.; Macdonald, R.; Fitton, J.G.; George, R.; Smith, M.; Barreiro, B. Two mantle plumes beneath the east African rift system: $\mathrm{Sr}, \mathrm{Nd}$ and $\mathrm{Pb}$ isotope evidence from Kenya Rift basalts. Earth Planet. Sci. Lett. 2000, 176, 387-400. [CrossRef]

48. Griffin, W.L.; Wang, X.; Jackson, S.E.; Pearson, N.J.; O’Reilly, S.Y.; Xu, X.S.; Zhou, X.M. Zircon chemistry and magma mixing, SE China: In-situ analysis of Hf isotopes, Tonglu and Pingtan igneous complexes. Lithos 2002, 61, 237-269. [CrossRef]

49. Zhou, M.F.; Micheal lesher, C.; Yang, Z.Z.; Li, J.W.; Sun, M. Geochemistry and petrogenesis of $270 \mathrm{Ma}$ $\mathrm{Ni}-\mathrm{Cu}$-(PGE) sulfidebearing mafic intrusions in the Huangshan district, Eastern Xinjiang, Northwest China: Implications for the tectonic evolution of the Central Asian orogenic belt. Chem. Geol. 2004, 209, $233-257$. [CrossRef]

50. Aulbach, S. Craton nucleation and formation of thick lithospheric roots. Lithos 2012, 149, 16-30. [CrossRef]

51. Gu, X.Y.; Ingrin, J.; Deloule, E.; France, L.; Xia, Q.K. Metasomatism in the sub-continental lithospheric mantle beneath the south French Massif Central: Constraints from trace elements, Li and $\mathrm{H}$ in peridotite minerals. Chem. Geol. 2018, 478, 2-17. [CrossRef]

52. Zheng, Y.C.; Hou, Z.Q.; Li, Q.Y.; Sun, Q.Z.; Liang, W.; Fu, Q.; Li, W.; Huang, K.X. Origin of Late Oligocene adakitic intrusives in the southeastern Lhasa terrane: Evidence from in situ zircon U-Pb dating, Hf-O isotopes, and whole-rock geochemistry. Lithos 2012, 148, 296-311. [CrossRef]

53. Hofmann, A.W.; Jochum, K.P.; Seufert, M.; White, W.M. Nb and Pb in Oceanic Basalts-New Constraints on Mantle Evolution. Earth Planet. Sci. Lett. 1986, 79, 33-45. [CrossRef]

54. Pearce, J.A. Geochemical fingerprinting of oceanic basalts with applications to ophiolite classification and the search for Archean oceanic crust. Lithos 2008, 100, 14-48. [CrossRef]

55. Dilek, Y.; Furnes, H. Ophiolite genesis and global tectonics: Geochemical and tectonic fingerprinting of ancient oceanic lithosphere. Geol. Soc. Am. Bull. 2011, 123, 387-411. [CrossRef]

56. Wang, R.Q.; Qiu, J.S.; Yu, S.B.; Lin, L.; Xu, H. Magma mixing origin for the Quxu intrusive complex in southern Tibet: Insights into the early Eocene magmatism and geodynamics of the southern Lhasa subterrane. Lithos 2019, 328, 14-32. [CrossRef]

57. Chauvel, C.; Marini, J.C.; Plank, T.; Ludden, J.N. Hf-Nd input flux in the Izu-Mariana subduction zone and recycling of subducted material in the mantle. Geochem. Geophys. Geosyst. 2009, 10, Q01001. [CrossRef]

58. Iizuka, T.; Yamaguchi, T.; Itano, K.; Hibiya, Y.; Suzuki, K. What Hf isotopes in zircon tell us about crust-mantle evolution. Lithos 2017, 274, 304-327. [CrossRef]

59. Ma, L.; Wang, B.D.; Jiang, Z.Q.; Wang, Q.; Li, Z.X.; Wyman, D.A.; Zhao, S.R.; Yang, J.H.; Gou, G.N.; Guo, H.F. Petrogenesis of the Early Eocene adakitic rocks in the Napuri area, southern Lhasa: Partial melting of thickened lower crust during slab break-off and implications for crustal thickening in southern Tibet. Lithos 2014, 196, 321-338. [CrossRef]

60. Yang, C.H.; Xu, W.L.; Yang, D.B.; Wang, W.; Wang, W.D.; Liu, J.M. Petrogenesis of Shangyu gabbro-diorites in western Shandong: Geochronological and geochemical evidence. Sci. Chin. Ser. D Earth Sci. 2008, 51, 481-492. [CrossRef]

61. Qu, X.M.; Hou, Z.Q.; Li, Y.G. Melt components derived from a subducted slab in late orogenic ore-bearing porphyries in the Gangdese copper belt, southern Tibetan plateau. Lithos 2004, 74, 131-148. [CrossRef]

62. Zhao, Z.D.; Mo, X.X.; Zhang, S.Q.; Guo, T.Y.; Zhou, S.; Dong, G.C.; Wang, Y. Post-collisional magmatism in Wuyu basin, central Tibet: Evidence for recycling of subducted Tethyan oceanic crust. Sci. Chin. Ser. D Earth Sci. 2001, 44, 27-34. [CrossRef]

63. Guo, Z.F.; Wilson, M.; Zhang, M.L.; Cheng, Z.H.; Zhang, L.H. Post-collisional Ultrapotassic Mafic Magmatism in South Tibet: Products of Partial Melting of Pyroxenite in the Mantle Wedge Induced by Roll-back and Delamination of the Subducted Indian Continental Lithosphere Slab. J. Petrol. 2015, 56, 1365-1405. [CrossRef] 
64. Nabelek, J.; Hetenyi, G.; Vergne, J.; Sapkota, S.; Kafle, B.; Jiang, M.; Su, H.; Chen, J.; Huang, B.S.; Hi, C.T. Underplating in the Himalaya-Tibet collision zone revealed by the Hi-CLIMB experiment. Science 2009, 325, 1371-1374. [CrossRef]

65. Mo, X.Z.; Dong, G.C.; Zhao, Z.D.; Guo, T.Y.; Wang, L.; Chen, T. Timing of magma mixing in the Gangdise magmatic belt during the India-Asia collision: Zircon SHRIMP U-Pb dating. Acta Geol. Sin. Engl. 2005, 79, 66-76.

66. Annen, C.; Blundy, J.D.; Sparks, R.S.J. The genesis of intermediate and silicic magmas in deep crustal hot zones. J. Petrol. 2006, 47, 505-539. [CrossRef]

(C) 2020 by the authors. Licensee MDPI, Basel, Switzerland. This article is an open access article distributed under the terms and conditions of the Creative Commons Attribution (CC BY) license (http://creativecommons.org/licenses/by/4.0/). 